Canadian Journal of Family and Youth, 13(1), 2021, pp. 125-129

ISSN 1718-9748@ University of Alberta

http://ejournals,library,ualberta.ca/index/php/cjfy

\title{
Thistle, Jesse. (2019). From the Ashes: My Story of Being Metis, Homeless, and Finding my Way. Toronto: Simon \& Schuster Canada.
}

\section{Reviewed by: Breanna Golosky, MacEwan University}

Jesse Thistle's book, "From the Ashes", is a compelling memoir about his struggle with addiction, homelessness, and his wandering soul. This memoir recounts Thistle's hardships he was faced with since he was abandoned at a young age, along with his brothers. Thistle battled his whole life thinking he would never amount to anything. This book is the journey of a lost man searching for decades for what he never truly believed was achievable for him. "This place isn't my home anymore, I think. Maybe it never was" (p. 345). Thistle recounts the battle he fought, and his memoir ends powerfully with the life he was able to make for himself on the other side of addiction.

The battle for his life began when he was abandoned as a young child along with his brothers, leading to a lifetime of unstable family relationships. Blanche Morrissette, Thistle's mother, let their father take them away because she could no longer deal with the father's drug habit. Sonny Thistle, Thistle's father, was a con man and a thief; he would use Thistle and his two older brothers to his advantage to scrounge up some change for food and drugs. He always shared the food with the boys but would spend all their extra money on drugs. Eventually Sonny was arrested, and the boys were put into the foster care system. They were not there long before their paternal grandparents, Jackie and Cyril Thistle, stepped in to take all three boys away and back to their house. The boys were not meant to be with their grandparents long, just until Sonny got out 
of jail to come and get them, but he never showed up. Thistle's grandparents continued to raise and nurture the three boys but there was always fear of the physical punishments that Cyril would dish out. Jackie told Thistle that physical punishment was the only way grandpa knew how to punish, because that is how he was raised (pp. 104-106). As Thistle grew older, he watched his grandmother answer the phone every night hoping it was Sonny calling home. This unstable foundation in Thistle's life led him to make bad choices. He started doing drugs and when his grandparents found out, they turned their back on him completely and kicked him out of the house. Thistle's grandparents had already watched their son battle the addiction and they were not going to let Thistle get away with it.

Thistle's battle with homelessness began when his grandparents' home was no longer a place where he was welcomed. Thistle bounced around to anywhere that would have him; homeless shelters, friends' couches, even sleeping in his friend Leeroy's car for some time. Thistle ended up on his uncle's couch for a while but left when he was confronted again by the haunting image of his father who was off somewhere alive but not looking for his sons. Being homeless caused Thistle to make even more poor choices. Thistle needed a place to stay and broke into Leeroy's house, breaking his trust and ruining the one true friendship he had left even though he knew it was wrong. Being homeless also led Thistle to cross paths with many bad people; many with the potential to kill him. His social circle reinforced ideals of violence and drugs which trapped Thistle in a continuous cycle with seemingly no way out.

The violence Thistle faced was recurring and a constant threat. Violence came in all areas 
of his life, the punishments he got from his grandfather were just the beginning. Thistle would routinely fight other kids in the school yard; it was his form of control because he would be made fun of for his bad grades, or for not having parents, or for his skin tone. Thistle received many racist threats while in the school yard; "You'll probably die drinking like they all do" (p. 87) is only one example. Thistle reacted to racist remarks like this with violence because that was the only way he knew how to combat it. As he got older and got into more trouble, Thistle faced many more dangerous and violent situations. During one particular drug deal, Thistle had a gun pressed against his head so hard that it left a bruise and a lingering fear for how close to death he was in that moment (p. 229). The people Thistle encountered regularly faced similar struggles such as vying for survival and spending all of their money on drugs and alcohol. Two of the people Thistle had met in a shelter, Stefan and Mike, used any means possible to get money so they could purchase more drugs. One of these means included murdering a taxi driver which Thistle found out about and informed the police. He did not believe it was morally right to kill someone for money, but no matter what he believed, he was still branded a rat (p. 209) and was constantly attacked for defying the code of the streets. Violence followed Thistle everywhere in the streets, in shelters he was living in, even in jail he was targeted and attacked just for whistling. Violence never seemed to let up, even when he was at his lowest.

The hardest battle that Thistle had to fight was the battle against drugs. Drugs were his downfall, leading him to homelessness, and placing strain on his relationship with his family. It was a quick downfall for Thistle from when he first tried marijuana because two months later, he 
was selling drugs and doing many others. Thistle's addiction to drugs put him in many situations that he otherwise might have avoided. One drug in particular, ecstasy, was something he took before some of the worst experiences of his life. He had cheated on his girlfriend while on ecstasy and he was filled with shame for betraying someone that meant so much to him. Thistle was also sexually assaulted while on ecstasy at a club. Drugs seemed to offer a source of comfort for Thistle and he turned to them during many hardships of his life. When he was awaiting the murder trial for his two friends, he was constantly smoking and drinking, trying to ignore the paranoia that he would still get in trouble even though he had nothing to do with the murder (p. 212). Even after his suicide attempt when he swallowed a bottle of Tylenol, Thistle would still go out and do drugs. It was an addiction that he thought he would never overcome.

After all the turmoil Thistle had been through, his body was on the brink of giving out. For a decade, Thistle was feeding his body an array of drugs, often never eating for days, and sleeping on the streets. Thistle knew his life needed to be turned around because he was not going to survive like that for much longer. Arguably, one of the most important lessons Thistle ever learnt was when he was in jail and it was the idea of giving to others freely with no strings attached. "Give to the next man and the next man prosper with you" (p. 254). His time in jail taught Thistle of the importance of giving to others and trusting them, knowing they would have his back because they mutually saw each other as trusting human beings.

Thistle's first time through rehab did not help him but the second time around Thistle was desperate. He was arrested again and so he called the Harvest House for one last attempt at a sober 
life. Thistle's second time through the Harvest House program was monumental for his success. He finished his GED and did not care what the others thought about him for taking the program so seriously. He knew that those who did not take it seriously were the ones that left early, just like he had once. His new path and outlook on life led him to completing the sobriety program and graduating to the reintegration program. Part of reintegration was to reconnect with people. Thistle reconnected with a woman he knew from his past lifetime in elementary school. They fell in love and she pushed him to become a better man. He got a higher education, still fighting his thoughts that he did not deserve it and learnt all about his heritage. Thistle was able to reconnect with his family and learnt to live his life in a way that made him and everyone around him proud. "From the Ashes" was such a compelling read filled with many heart wrenching tragedies, you cannot help but root for Thistle throughout the whole book. I recommend this book to anyone that is interested in stories that are not only raw and gut wrenching but are triumphant and victorious; to those that root for the underdog. The specific academic audience this book relates to is anyone studying intergenerational trauma or the impact of homelessness and addiction on the Indigenous community. In a broader sense, this book would be of interest to disciplines such as sociology, psychology, or medical studies. 